\title{
Editorial: Community Informatics with a Latin Accent
}

\author{
Michael Gurstein \\ Editor-in-chief, JoCI, < editori@ci-journal.net > \\ Para el texto en español, por favor avance hasta el final de la versión en inglés.
}

This special Spanish language (the English translations will appear in the spring of 2008), Latin America issue of the Journal of Community Informatics represents a very significant departure, advance, maturing, and "leap forward" for JoCI and for Community Informatics in general.

While much of the early practical work in Community Informatics was done in conjunction with the extremely significant grassroots telecentre movement in Latin America (not incidentally, the origins of the Community Informatics Research Network can be found in a meeting held in conjunction with the Global Community Network Partnership in Buenos Aires in 2001) much of the writing concerning this work has been unavailable to English speaking audiences.

As well, the participation of Latin American Community Informatics researchers in the broader discussions and CI networking has been sporadic and limited by issues of funding, distance, linguistic barriers and the overall silos that continue to exist particularly for grass roots based initiatives even in this age of globalized communications and international travel.

So it is with particular delight that I welcome this issue of JoCI, and congratulate its Co-Editors Eduardo Villanueva (Peru) and Christoph Roessner (Ecuador).

This issue reflects the range of work currently being done both on the ground with community informatics implementations ranging from telecentres to supports for migrants to rural development support systems and including cases and examples from roughly 10 countries in the region. As well, there are presentations of some of the research, practice and policy dilemmas and opportunities including a discussion of the very interesting and innovative programs being implemented currently in Brazil.

Latin America is currently rediscovering its role as an independent player in the global scene and Latin America historically has deep traditions of community initiatives and community self-reliance. To a degree the community ICT initiatives presented in these papers links into these traditions but CI as a whole, I think, still waits for the development of what could be an explosive force which would emerge from a direct linkage of ICTs with the powerful grassroots movements that are just now coming to the fore in the region.

Each community and from there each local area and each nation finds unique ways of adapting and integrating ICTs into its local concerns and local struggles. The variety of these developments is only just now starting to become visible as the technology moves from being project (and thus externally) driven to becoming locally integrated ("appropriated") and in this way a natural and naturally evolving resource for community initiatives and empowerment. The strength of this and the power that will be unleashed when ICTs are "appropriated" by the range of community initiatives in Latin America will I think, give CI as a whole a new direction and bring CI much more directly onto the overall stage of ICT4D.

\section{Editorial: La informática comunitaria con un acento latino}

Esta edición especial sobre América Latina, en español (las traducciones al inglés estarán disponibles en el segundo trimestre del 2008) del Journal of Community Informatics representa un cambio muy significativo, un avance, muestra de madurez y "salto adelante" para JoCI y la informática comunitaria en general.

Si bien mucho del trabajo práctico temprano en informática comunitaria se realizó junto con muy importante movimiento de bases de telecentros en América Latina (no es casual que el origen de la Red de Investigación en Informática Comunitaria puede ubicarse en en una reunión conjunta con la Global Community Network Partnership en Buenos Aires el 2001), mucho de los escrito sobre esta temática en la región no ha estado disponible para el público de habla inglesa. 
Similarmente, la participación de los investigadores latinoamericanos en informática comunitaria en las discusiones más generales, y en el networking de la comunidad profesional, ha sido esporádico y limitado por problemas de financiamiento, distancia, barreras lingüísticas y la separación general que existe particularmente entre las iniciativas de base incluso en esta era de comunicación global y viajes internacionales.

Es por ello que me resulta particularmente grato darle la bienvenida a este número de JoCI, y felicitar a sus coeditores Eduardo Villanueva (Perú) y Christoph Roessner (Ecuador).

Este número refleja la diversidad de iniciativas que están llevando a cabo tanto en el terreno, con implementaciones de informática comunitaria que van de telecentros a apoyo a migrantes, a sistemas de soporte al desarrollo rural. Con casos y ejemplos de unos diez países de la region, también se cuenta con exposiciones de parte de los dilemas que la investigación, la práctica y la política plantean, incluyendo la discusión de programas innovadores, de mucho interés, que se están implementando en Brasil en la actualidad.

América Latina está en un proceso de redescubrimiento de su rol como un actor independiente en la escena global; hay en esta región una larga tradición de iniciativas comunitarias y de autodesarrollo comunitario. Hasta cierto punto las iniciativas comunitarias con TIC discutidas en estos artículos se enlazan con estas tradiciones, pero a mi criterio, la informática comunitaria, en conjunto, todavía espera el desarrollo de lo que podría ser una fuerza ponderosa que emergería de una relación directa entre las TIC con los potentes movimientos de base que están justo ahora tomando un sitio central en en la vida de la región.

Cada comunidad, cada region y cada nación encuentran formas únicas, originales, para adaptar e integrar las TIC en sus preocupaciones y luchas locales. La variedad de estos desarrollos es aparente solo desde hace poco, con la tecnología saliendo de su condición de proyecto, impulsada desde fuera, para convertirse en un recurso integrado a lo local, "apropiado" localmente, y de esta manera un recurso, naturalmente, en evolución natural, para el empoderamiento de las iniciativas locales. La fortaleza de esta situación, y el poder que será desencadenado cuando las TIC sean "apropiadas" por el conjunto de las iniciativas comunitarias en América Latina le darán, a mi criterio, una nueva, distinta, dirección a la informática comunitaria, y la pondrán mucho más en el centro del escenario de la ICT4D: TIC para el desarrollo. 